Michelle R. Garfinkel is an economist at the Federal Reserve Bank of St. Louis. Thomas A. Pollmann provided research assistance

\title{
The Causes and Consequences of Leveraged Buyouts
}

N THE MARKET for corporate control during the past decade, leveraged buyouts have become increasingly popular. Many observers, speculating about the causes of this recent trend, have expressed concern about the potential problems arising from such activity. ${ }^{1}$ Implicit in many casual discussions is the assumption that leveraged buyouts-hereafter LBOs-are merely some type of cosmetic surgery. That is, an LBO has no impact on the productive capacity of the target firm, while unjustifiably inflating the value of the stock.

Under this assumption, any observed gains to the existing shareholders of the target firm are likely to be matched, if not dominated, by losses to others; since there is no net gain and possibly a loss to society, LBO activity should be restricted. Some analysts also argue that LBOs have contributed to the unprecedented growth of outstanding debt in recent years. If, as many. contend, the large growth in debt is associated with increased instability in the financial system, public policy might aim to reverse or at least curb debt growth. In addition, tax reform might be an appropriate way to reduce this debt growth, if it stems chiefly from tax incentives.

This article examines whether LBOs have had a productive impact on the target firm. If economic theory and evidence suggest that LBOs generally are productive, then arguments for legal restrictions on LBO activity are less persuasive. Alternatively, if there are few, if any, gains from LBOs, the idea that LBOs pose a problem for the economy might be valid.

\section{WHAT APE LBOS?}

Despite the ever-expanding literature on LBOs, there does not appear to be a single, clear definition of what an LBO really is. Loosely speak. ing, an LBO is simply the purchase of a firm by an outside individual, another firm or the incumbent management with the purchase being financed by large amounts of debt; the resulting firm is said to be "highly leveraged." The target firm can be a free-standing entity or a division of a public corporation. ${ }^{2}$ Although the target of the LBO can be a private firm, recent discus. sions about LBO activity have focused primarily
'For example, see Lowenstein (1986), 'When Industry Borrows itself" (1988), Friedman (1989) and Kaufman (1989).

2When the target of an LBO is a division of a public company, the transaction is typically called a "management buyout." Stancill (1988), p. 18, who points out that LBO activity targeting smaller (private) firms is not a new phenomenon, provides a very general definition of an LBO: "whenever a buyer lacks the requisite cash and borrows part of the purchase price against the target company's assets (receivables, equipment, inventory, real estate) or cash flow (future cash), that's an LBO." 
on instances in which a public firm is taken private. $^{3}$ Upon this type of transaction, the target firm's stock shares are no longer traded publicly in equity markets.

The greatest ambiguity about what constitutes an LABO concerns the degree to which the purchase is financed with debt." Typically, debt finance provides about 80 percent to 90 percent of the funds for the purchase. Equity finance, in which the resulting shares are held by the purchasers of the target firm and, often, an outside investment group, provides the remaining funds. ${ }^{5}$

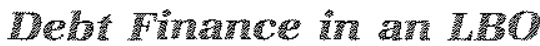

Two types of debt are usually employed in an LBO transaction: senior debt and subordinated debt. Senior debt typically accounts for the greatest proportion, usually 50 percent to 60 percent, of financing for the LBO. Sometimes called secured debt, senior debt specifies a lien on a particular piece of property. In the case that the firm's earnings are insufficient to service the firm's debt obligations fully, the holders of senior debt can have the pledged property sold to recover the unpaid interest and principal. Funds through senior debt are often provided by commercial banks, insurance companies, leasing companies and limited partnerships specializing in $\mathrm{LBOs}$ and venture capital investments. ${ }^{6}$

Subordinated debt, or "mezzanine" debt, is considered to be more speculative than senior debt because it is issued without a lien against specified property. Although the holders of subordinated debt are protected in the case of default, only assets not pledged explicitly and any cash remaining after paying other creditors are available to satisfy these unsecured claims. Accounting for about 30 percent of the financing for the transaction, subordinated debt is usually provided by pension funds, insurance companies and limited partnerships. ${ }^{7}$

\footnotetext{
3See Lehn and Poulsen (1988, 1989) and "Corporate America Snuggles Up to the Buy-Out Wolves"s (1988), for exampie. DeAngelo, DeAngelo and Rice (1984), p. 370 , use a narrower definition by making a distinction between pure going-private transactions, where "incumbent management seeks complete equity ownership of the surviving corporation," and leveraged buyouts, where "management proposes to share equity ownership in the subsequent private firm with third-party investors."

4The Federal Reserve Board recently established a set of guidelines for banks involved in a broader class of leveraged financing, called "highly leveraged financing." This class of leveraging includes all borrowers having debt-to-
}

In many LBOs, after the purchase, the new owners sell some of the firm's assets and use the proceeds to retire some of the debt. Cash flows from continued operations are used to service the remaining debt obligations.

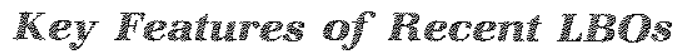

The typical LBO in recent years has two interesting characteristics that distinguish it from other takeover and merger activities. First, the equity of the target firm usually is held by fewer individuals following the financial reorganization. This increased concentration of ownership is especially typical of a "going-private" transaction in which the stock is no longer publicly traded. ${ }^{\text {s }}$

Second, although alternative sources of funds are available to obtain corporate ownership, going-private transactions usually are financed heavily with debt, leaving the target firm in a highly leveraged position. In essence, the transaction involves a substitution of debt for equity. For example, in a sample of 58 LBOs between 1980 to 1984 , the average debt-to-equity ratio rose from 0.457 to 5.524 , a percentage change exceeding 1100 percent. $^{9}$

The higher degree of leveraging means that a larger proportion of claims against the target firm's assets and operations are fixed obligations. Because holders of these claims can push the firm into bankruptcy if these obligations are not met fully, the greater leveraging, holding all else constant, erodes the target firm's insulation from unexpected declines in earnings and, hence, increases the firm's risk of bankruptcy.

\section{PECENT TRENDS 亘N LPO

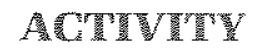

The following discussion defines an $\mathrm{LBO}$ as a highly leveraged, going-private transaction. This

total-asset ratios exceeding 75 percent. See "Board Issues Guidelines for LBO, Other Highly Leveraged Loans ..." (1989). Although LBOs are included in this class, they have not been specifically defined by the Federal Reserve Sysiem.

5Thomson (1989) and Lehn and Poulsen (1988, 1989).

stbid.

7lbid.

sMany of these firms, however, subsequently go public.

Tehn and Poutsen (1988), table 2, p. 48. 


\section{Table 1}

\section{L8O Activity, 1979-88, Going Private Transactions (dollar amounts in millions)}

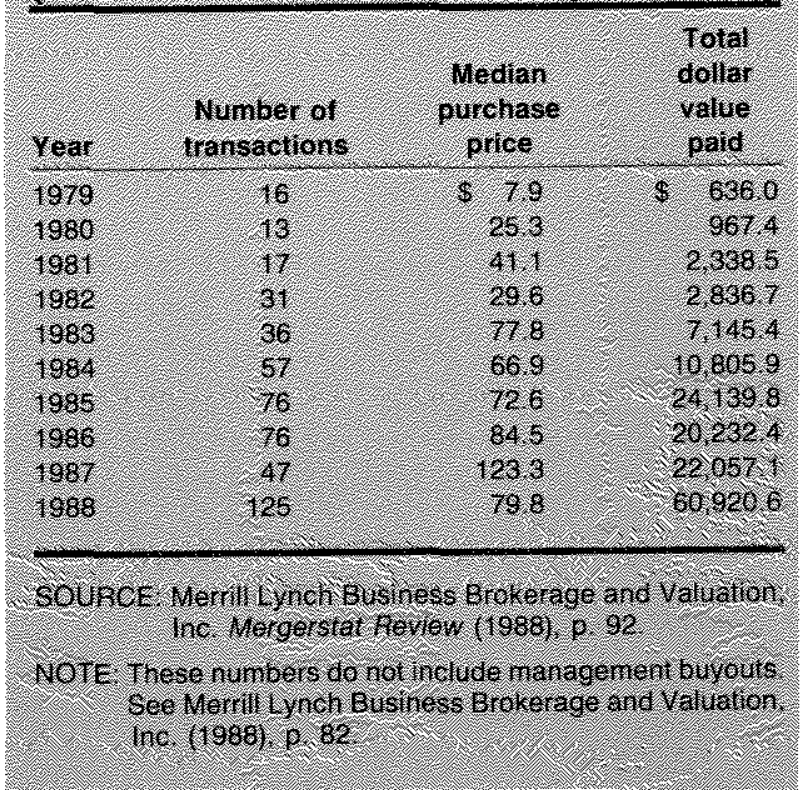

narrow focus permits the discussion to address recent concerns about LBO activity that appear to revolve around those transactions in which public firms are taken private primarily through debt financing.

As shown in table 1, the number of goingprivate transactions in 1988 was nearly eight times that in $1979 . .^{10}$ Just in the past year, the incidence of these transactions has more than doubled. Furthermore, the table indicates that the average as well as the median purchase price rose dramatically over the same period. In 1979 , the average purchase price was $\$ 39.8$ million, whereas in 1988 it was $\$ 487.4$ million. The average purchase price rose at an annual rate of 32.1 percent, nearly three times the $\mathbf{1 1 . 1}$ percent annual rate of increase in the value of

10Merrill Lynch Business Brokerage and Valuation, Inc, (1988) reports, "Like the majority of unit management buyouts, most, if not all, of the 'going private' transactions also are leveraged buyouts, i.e., transactions in which the buyers put up only a small part of the purchase price and borrow the rest." (p. 91) Management buyouts have also increased less markedly, from 59 in 1979 to 89 in 1988. See Merrill Lynch Business Brokerage and Valuation, Inc. (1988), p. 82 .

1tLehn and Poulsen (1988), table 5, p. 52, report the premiums, as determined in the market, for the target firms of LBOs included in the COMPUSTAT data tape be-

\section{Table 2}

\section{Premium Paid Over Market Price} in $\mathrm{LBOS}$

\begin{tabular}{|c|c|c|}
\hline rear & fvergage & Medra \\
\hline 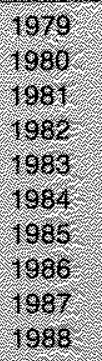 & 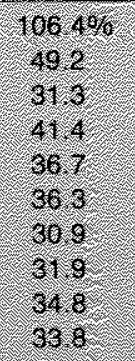 & 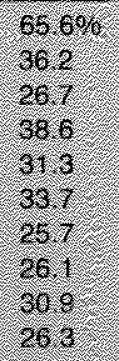 \\
\hline \multicolumn{3}{|c|}{ 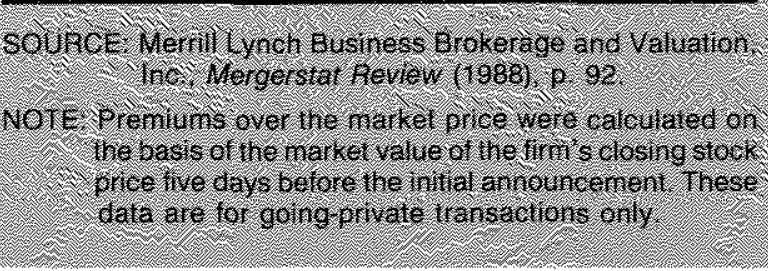 } \\
\hline
\end{tabular}

firms included in the New York Stock Exchange. Even accounting for inflation, the increase in the average purchase price was substantialfrom $\$ 50.6$ million to $\$ 400.5$ million in 1982 prices, a real annual growth rate of 25.8 percent.

While the average purchase price generally rose during the $1980 \mathrm{~s}$, the "premium" or the price paid for these firms above their initial market value (the value of their stock shares before the initial announcement) as a percent. age of the market value has been relatively stable. As table 2 shows, average and median premiums paid over the prior market price of the target firms from 1979 to 1988 have been quite large. Even excluding the extremely large 1979 values, the average and median premiums averaged about 36.3 percent and 30.6 percent, respectively. ${ }^{11}$ These large premiums indicate tween 1980 and 1984. The "market-valued" premium was measured as the percentage increase in the stock price from 20 days before the LBO announcement until the day of the announcement for LBOs between 1980 and 1984 . They find that market-valued premium as a percentage of the market price before the announcement averaged 39.5 percent, ranging from 1.7 percent to 120 percent. During the same period, the "cash-offer" premium (the cash offer above the market price 20 days before the announcement) as a fraction of the market price ranged from 2 percent to 120 percent, averaging 41 percent. The sample standard deviation of both these premiums was 23.2 percent. 
that the target firm's stockholders have captured significant capital gains upon the LBO transaction. $^{12}$

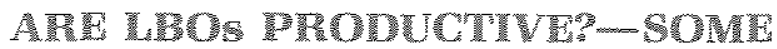

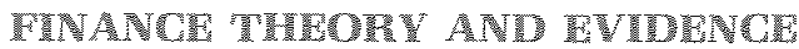

The growing incidence of LBO activity in the market for corporate control has sparked many to question the social value of this activity. Many expressed concerns are predicated im. plicitly on the notion that the changes in the firm's financial structure associated with the LBO transaction have no positive real effects on that firm's output. If the transaction were merely a device to realize some short-term gain, at the expense of long-term growth and a reduction in social wealth, then these concerns would be justified.

Finance theory, however, suggests that LBOs can be productive. The gains derive from two key features of LBOs in recent years-namely, going private and highly leveraged financing. These related features permit a reorganization of the firm to alter its incentive structure and produce an increase in its earnings potential.

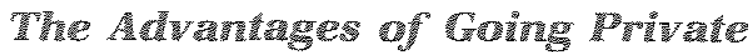

The theory of corporate finance shows how the distinction between ownership and control, or equivalently the differences between the in centives and constraints of the firm's stockholders and those of the firm's managers, can have important implications for the perfor. mance of the firm. Specifically, this distinction can create a situation in which the firm does not achieve its maximum earnings potential-

\footnotetext{
12Also, see DeAngelo, DeAngelo and Rice (1984), Torabzadeh and Bertin (1987) and Lehn and Poulsen (1988, 1989), who find that announcemenis of LBOs have significant positive effects on the target firm's stock price. For example, Lehn and Poulsen (1989, p. 776) calculate the average daily return from holding the stock of the target firm of the LBO for various holding periods, abstracting from movements in the firm's stock price due to economywide factors. They find that the "cumulative average daily abnormal return" (CAR) from 20 days before to 20 days after the LBO announcement averaged 20.54 percent across the firms included in the sample during the period 1980-87. This means that an individual buying a stock of an LBO target 20 days before the announcement and then selling it 20 days after the announcement could have made a 20.5 percent return on average above a normal (the market) return over the same period. Even holding the stock from one day before the announcement until the end of the announcement day yielded, on average, a CAR of 16.3 percent, a return too high to be attributed solely to
}

that is, the firm is not being run efficiently from the stockholder's perspective. ${ }^{13}$ By going private, the distinction is removed and eamings can increase. ${ }^{14}$

If the manager's actions were monitored easily and costlessly, going-private transactions would have no implications for the performance of the firm. A contract for compensating the manager could be designed by the owners to encourage the manager to act entirely on their behalf. The ideal contract would specify the appropriate actions to be taken by the manager to maximize the firm's value under all possible contingencies; the contract would penalize the manager if he failed to act in accordance with its specifications, thereby ensuring that the manager always acted in the interests of the owners.

The efficacy of such contracts, however, hinges on the ability and costs of monitoring. Typically, the firm's owners do not observe the actions of the managers directly, nor are they fully aware of the economic environment (specific to the firm) in which a manager's decisions are made. For example, owners do not have complete information about the firm's opportunities for investment and growth or about the daily events that influence a manager's decisions. Holding all else constant, as the number of the holders of the firm's stock increases,that is, as the firm's ownership becomes more dispersed-the potential gains realized by one owner monitoring the manager's actions decline, because the potential net gains that the individual can capture become smaller relative to the costs he incurs. In this case, monitoring activity declines and contracts designed to align the man- chance. Similarly, for the period 1973-80, DeAngelo, DeAngelo and Rice (1984), pp. 394-95, estimate a signifjcant CAR of 16.99 percent for the same holding period.

13For example, see Manne (1965) and Jensen and Meckling (1976).

${ }^{34}$ Another gain from going private, which is more obvious, involves circumventing the explicit costs that are otherwise incurred with outside ownership, such as registration and listing fees and other stockholder service costs. Relative to the market value of the public firm, these explicit costs can be significant. For example, in the early 1980s, estimates of the costs of public ownership incurred annualIy ranged from $\$ 30,000$ to $\$ 200,000$. The value of the stream of this annual cost (for an indefinite time) discounted at a rate of 10 percent, ranges from $\$ 300,000$ to $\$ 2,000,000$, whereas the median value of a sample of 72 firms attempting to go private between 1973 and 1980 was $\$ 2,838,000$. See DeAngelo, DeAngelo and Rice (1984) and references cited therein. 
ager's incentives with those of the owners cannot be enforced completely.

To see why the distinction between ownership and managerial control can be important when monitoring incentives are weaker, consider the following extreme example in which a firm has such a large number of owners that no individual finds it worthwhile to monitor the manager at all. As is typical in any publicly owned firm, the owners have voting rights, but do not participate directly in the daily opera" tions and decision-making of the firm. Suppose that the firm's manager, who exercises full control over these operations, has the opportunity to undertake a new project whereby the present value of cash flows (that is, revenues net of operating costs) can increase by $\$ 100$. If the manager had a fixed salary and no ownership claims in the firm, he would be completely indifferent between exploiting this opportunity and not doing so, as long as the expansion required no additional time by the manager. If the expansion actually required any additional time, however, he might well choose to forgo the opportunity; after all, what's in it for him?

In this example, the distinction between ownership and control is meaningful because the manager does not fully bear the wealth consequences of his actions. In the absence of effective monitoring by the owners, the decisions of the manager, acting on his own behalf, are not likely to maximize the owners' wealth; instead, they will maximize the manager's utility.

As the distinction between ownership and control becomes less clear, the conflict of interests between owners and managers becomes less severe. In the example above, if the manager owned a fraction of the firms' stock, say 5 percent, he would be less reluctant to initiate the new project; the additional cash flow created by the new project would increase the total value of his stock and wealth by $\$ 5$. Nevertheless, the manager would not act entirely on behalf of all the owners unless the marginal gain from doing so, $\$ 5$ in this example, exceeded the marginal value of his time used in other ways, including leisure.

The problems that potentially arise from the distinction between ownership and control, called "agency problems," explain why we observe managerial contracts that are more complicated than those that simply specify a fixed income. The problem of "incomplete monitoring" explains why the observed managerial contracts are less complicated than those that could perfectly remove the conflict of interests between owners and managers. A contract that partially links the manager's income to the firm's characteristics observed easily by stockholders-for example, sales, profits or the firm's stock performance-could help alleviate the conflict. ${ }^{15} \mathrm{~A}$ change in the organizational structure of the firm, such as that engendered by an LBO, however, is another and potentially more effective method to circumvent the firm's organizational inefficiencies attributable to the meaningful separation of control and ownership.

In a going-private transaction, the interests of owners and the manager generally are closely, if not fully, reconciled. Once the manager becomes the owner, there is no conflict; the wealth consequences of the manager's actions are entirely internalized by the firm's reorganization. Even when a third party (another company or an individual) finances the purchase, monitoring possibilities improve, simply because the transaction decreases the number of owners-or, equivalently, concentrates the ownership of the firm-thereby rais" ing the level of monitoring and the possibility that enforceable contracts can be designed to resolve the conflict of interests more effectively. By improving the organizational efficiency of the firm through a change of ownership, the LBO can increase the firm's earnings. ${ }^{16}$
15Note that a manager who dislikes risk would not willingly enter into a wage contract specifying that his compensation be a function only of the markel value of the firm's stock. Doing so would involve taking on a large amount of risk-i.i.e., possible, large fluctuations in income that are not entirely under his control. Provided that there is competition in the market for managers, owners of the firm must bear some of the risks and offer a compensation schedule such that risks are shared by owners and managers. Bennett (1989), however, reports that executives increasingly are taking on some of the risks, in the sense that the link between their salaries and the markel value of the firm, through long-term incentive schemes (such as stock options and restricted stock), has become substantial over the past decade. In the absence of complete monitoring, the problems that typically arise from the distinction between ownership and control are being partly mitigated by tying executive compensation to the performance of the firm.

${ }^{16}$ An inefficient organization of a firm provides a motivation for others to take over that firm. Note that such a takeover need noi involve taking that firm private. Rather, the takeover is necessary to reorganize the firm to effect a higher concentration of ownership. 


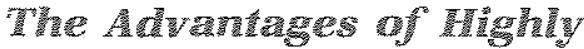

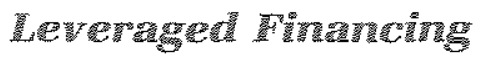

That most going-private transactions are financed with a large proportion of debt sug. gests that leveraging itself must augment the potential gains from the buyout. That is, the high degree of leveraging in the buyout need not indicate that the buyers do not have the requisite cash for the transaction.

One widely mentioned source of gain from extensive leveraging is based on the incentive structure of the tax system. Because interest payments on debt are tax deductible, debt financing is relatively more attractive (ceteris paribus) than other methods of finance. The double taxation of dividends, first as corporate income and then as shareholder income, further increases the incentive to issue or sell debt to finance the purchase of the firm.

The gain from leveraged financing, however, need not be restricted to reducing the tax liability of the target firm. Another motive for the use of debt finance stems from the misalignment of the manager's incentives with those of the owners in cases where the firm faces low growth prospects and a large "free cash flow." When the firm's cash flow exceeds what is necessary to finance its own projects that are expected to yield positive (discounted) net revenues, the firm is said to have a positive free cash flow. That is, the firm has reached its optimal size; additional projects to expand its operations would not maximize its profits.

There are cases, however, in which the manager of a firm that has reached its optimal size might choose not to maximize the shareholders' wealth by paying out the free cash flow in the form of dividends. For example, if the manager's compensation were linked to the firm's growth in sales, he would have a greater incentive to invest the free cash in any project that increases the firm's sales, even if the pro- ject's net return would be insufficient to maintain the firm's value. The incentive to use the free cash inefficiently (from the stockholders' and society's perspective) to increase the firm's size is greater if the manager values his power as measured by the amount of resources under his control. ${ }^{18}$ In this case, the market value of the stock and the wealth of existing shareholders will not be maximized.

The problem of free cash flow, a particular type of agency problem, can be mitigated in a buyout that is financed with debt. Issuing debt and using the entire proceeds to purchase equity in an LBO enables the stockholders to capture the present value of the future free cash flow that otherwise would be used inefficiently. The firm's increased leveraged position after the transaction, in effect, imposes a binding commitment on the manager to not waste future cash flow; specifically, the manager cannot repudiate the firm's debt obligation to pay out the future free cash flow as interest payments because the bondholders could then push the firm into bankruptcy. By circumventing or reducing the agency problem associated with free cash flow, the use of debt essentially improves the productive efficiency of the firm.

\section{Pideree}

The empirical observation that the purchase price in an LBO is, on average, considerably higher than the market price before the LBO announcement suggests that these transactions have increased the value of the target firm and, hence, the wealth of the shareholders. ${ }^{19}$ The observed gain to shareholders is consistent with the notion that market participants at least expect the changes brought about by the $\mathrm{LBO} \mathrm{ac}^{-}$ tivity to be productive. ${ }^{23}$

The basic idea here is that by increasing the efficiency with which the firm's resources are used, the LBO transaction is expected to in-

\footnotetext{
17Jensen (1986, 1988). Also see "Management Brief: The Way the Money Goes" (1989) for a brief discussion of this hypothesis as well as others to explain the increasing degree of leveraging by cofporations in recent years and Laderman (1989a) for a discussion of the concept of free cash flow and its relation to cash flow and operating cash flow.

18 Of course, free cash flow could also explain the growing acquistion activity that has gerefated losses to stockholders. See Jensen $(1986,1988)$ for detais.

is See the evidence cited in footnotes 1 t and 12
}
20The issue of whether merger and acquisition activity in general is productive has also received attention by researchers in finance as well as the news media. See Jarrell, Brickley and Netter (1988) and Jensen and Puback (1983) for recent reviews of the empirical siudies on the effects of merger and takeover activity. These sludies generally indicate that stockholders gain, on average, from this activity in the market for corporate controf. Also, see Ott and Santoni (1985) who present a useful theoretical discussion of the productiveness of mergers and acquisi- tions and place this activity into an historical perspective.


crease economic earnings, which would eventually be paid out as dividends. Because the price of a firm's stock is equal, in theory, to the expected present discounted value of future dividends, the transaction also raises the price of the stock. In equilibrium, the gains to stockholders or the premium paid over the market price before the transaction should be identical to the expected increase in the present discounted value of economic earnings to the target firm. ${ }^{21}$

In an attempt to identify the sources of the increase in value from LBOs, one recent study found that the increase in the market price of the target firm's stock is largely explained by its cash flow as a fraction of the market value of its equity before the transaction. ${ }^{2.2}$ This evidence suggests that, with greater cash flow and the greater agency costs potentially associated with that flow, there is more room to improve the firm's productive efficiency and, accordingly, to increase the firm's value. Indeed, although differences in the firm's tax liabilities are assoctated with significant differences in the observed magnitudes of the premiums, measures of the firm's tax liability do not add statistically significant information for predicting the marketvalued premium above the information provided by the cash flow measure. ${ }^{23}$ Hence, the expected gains from the LBO transactions appear to be over-and-above the tax advantages of debt finance.

\section{SEPPTCWBM AROUT TIE SOCHA VAUUR OT LBOS}

Despite the gains typically realized by a target firm's shareholders, some observers have $\mathrm{ex}$ pressed doubt about the benefits of LBOs. These doubts stem from two types of potential "bad" effects of LBOs: wealth redistributions and increased instability of the economy.

\section{LEOS ard Wealth Fedistributions}

One version of the redistribution criticism is the claim that LBOs generate gains for the stockholders at the expense of those holding the target firm's original bonds; the redistribution presumably results from a reduction in the
${ }^{21}$ For example, in the simple case where expected future dividends, $d$ for $t>0$, grow at a constant rate, $g$, the price of the firm's stock can be written as $\frac{d_{1}}{k-g}$. I is the constant discount rate appropriately adjusted tor risk, and $d_{1}$ is next period's dividend payment. Hence, by increasing expected dividends ( $d_{t}$ or $g$ )-or, equivalently, expected economic earnings - the transaction can increase the market value of the firm's stock.

Assuming that makket participants correctly value the firm's stock, the observed increases in the stock price cast some doubt on the general criticism of activity in the market for corporate control, that managers are exploiting opportunities for short-term gains at the expense of longterm performance. Rather, this activity effectively removes myopic incentives so as to increase long-term economic earnings. Of course, the claim that observed unusual increases in the stock price supports the hypothesis that mergers and acquisitions are productive presumes that capital markets are efficient. In particular, firms are not systematically undervalued (given public information) and daily changes in the price of the firm's stock reflect new information that is made available to the public and is relevant for determining the firm's value. Otherwise, the observed increase in the stock price could merely reflect a re-evaluation of the firm's productiveness, without any fundamental change expected to arise from this activity in the market for corporate control.

22Lehn and Poulsen (1988), table 6, p. 54. The measure of cash flow used in their empirical analysis, however, does not control for the firm's growth prospects and so only crudely captures the fitm's "free cash flow." But in a subsequent analysis, Lehn and Poulsen (1989), using undistributed cash flow (that is, the firm's after-tax cash flow net of interest and dividend payments) and attempting to control for the firm's growth prospects, get similat results for LBOs between 1984 and 1987 (table V, p. 782). Also,
Lehn and Poulsen (1989), table 1ll, p. 778 , find that firms going private have a significantly higher flow of undistributed cash flow as a fraction of their equity value and possibly lower growth prospects than a control group of firms.

Recently, Mitchell and Lehn (1988), who attempt to identify the source of gains to shareholders in takeover activity, present some preliminary evidence to support the hypothesis that the growth in productive takeover activity is partly an attempt to prevent the target firm from using free cash flow in an unprofitable way or to reverse the earlier unprofitable takeover activity due to the free cash flow problems.

23Lehn and Poulsen (1988, 1989). Lehn and Poulsen (1988), table 9, p. 60 , divide their sample into two equal subsamples according to the magnitude of the firm's tax liability as a fraction of the market value of the firm's outstanding equity before the transaction. They find that the mean marketuvalued premium for those firms with the higher tax liability measure was 47.7 percent, whereas that for firms with the lower measure of tax liability was 32.1 percent. The difference in the premiums for the two subsamples cannot be due to chance alone. (See footnote 11 for their definition of the market-valued premium.) However, the firm's tax liability does not explain variation in the premium not already explained by variation in the firm's undistributed cash flow. See Lehn and Poulsen (1989), table V, p. 782. Also, they do not find a significant difference between the mean tax liability for firms that went private and that for a control group of firms (table III, p. 778 ). 
market value of the firm's outstanding debt. ${ }^{24}$ The value of debt allegedly falls because the target firm's increased leveraged position, typically in the form of low-quality, highyielding (junk) bonds, increases the probability that its future revenues will be insufficient to cover its higher interest payments. That is, the value of the firm's bonds outstanding before the announcement of the LBO drops because market participants believe that the probability of default has increased as a result of the LBO transaction. ${ }^{25}$

Even if LBOs were to redistribute wealth in this way, however, whether or not public policy should aim to discourage LBO activity is not obvious ${ }^{26}$ Economics has nothing meaningful to say about the "fairness" of wealth redistributions that leave social wealth unchanged. The key economic issue is whether LBOs reduce the market value of the firm's outstanding debt by more or less than the increase in the value of its outstanding stock. If the net change in the value of stockholder's' and bondholders' claims on the firm is negative, then LBOs reduce social wealth. In this case, LBOs would be socially inefficient and public policy to limit such activity could be justified.

The evidence discussed above, however, casts some doubt on the validity of the claim that LBOs merely redistribute wealth among those having claims in the firm with no net gain to society. Specifically, the alleged positive effect of the increase in leveraging on the firm's default probability should not emerge. If such an effect were to emerge, it would first be reflected in the price of the stock. Because the new owners of the firm will be the residual claimants of the firm's earnings, they take on the greatest amount of risk in the transaction. The bidders must expect that, while future debt-servicing increases, the LBO will improve the firm's productivity so

24for example, see "A Big Event for American Bonds"

(1988) and, "When Industry Borrows Itself" (1988).

${ }^{25}$ The value of preferred stock is also said to fall. Specified payments or dividends, distributed to holders of these stock shares unless earnings are insufficient to cover interest payments on outstanding debt, are fixed like interest payments on debt.

26The forms of protection, offered in financial markets, against such losses weakens the role for public intervention. See, for example, "The Debt Deduction" (1988) and Lehn and Poulsen (1988).

27Lehn and Poulsen (1988), table 8, p. 57. Also, see Marais, Schipper and Smith (1989) who similarly find that bond values did not significantly decline following 290 proposed management buyouts between 1974 and 1985 . Further- as to augment the future cash flow available for servicing that increased debt obligation; otherwise, they would not be willing to pay such a premium to purchase the firm.

Confirming this line of reasoning, empirical studies indicate that LBO announcements have an insignificant effect on the market value of the firm's outstanding debt. One study found that, for a sample of 13 target firms between 1980 and 1984, the average percentage change in the bond price from 10 days before to 10 days after the announcement was -1.42 percent, much smaller than the average 7.21 percent decline in the Wall Street Journal's 20-bond index over the same period. ${ }^{27}$ Another study of 20 LBOs between 1984 to 1988 found that the likelihood of the bond price falling was virtually equal to the likelihood of the price increasing upon the LBO announcement. ${ }^{28}$ However, a recent study found that, for 33 successful buyouts between 1974 and 1985, the default risk of the target firms' bonds (as measured by Moody's) typically increased. ${ }^{29}$

Another version of the redistribution hypothesis is based on the widely cited reason for the recent growth of LBOs-that is, the tax system produces a bias for debt finance. By reducing the firm's tax liability, the LBO increases the firm's after-tax earnings and, consequently, the market value of the firm's stock. According to some observers, the observed increase in stock value takes place at the expense of taxpayers. Because these transactions permit the target firms to reduce their tax liability, tax gains to the target firms realized by the shareholders are said to be offset indirectly by increasing the tax liabilities of all taxpayers. ${ }^{30}$

Regardless of the issues related to the fairness of the tax system, the critical economic issue for public policy toward LBOs is whether the

more, preferred stock values do not appear to be significantly affected by the amouncement.

zaFortier (1989). Out of a sample of 20 LBOs, the bond prices of only eight target firms fell. The average change in price as a percentage of the bond's face value, abstracting from general market interest rate movements was only -0.50 percent, too small to be attributed to the LBO an. nouncement. However, she finds that after January 1987 , when the elimination of preferential tax treatment of capital gains made debt finance even more attractive, bondholders, on average, experienced significant losses (5.1 percent).

29Marais, Schipper and Smith (1989), tables 8 and 9, pp. 184-85.

3o For example, see Lowenstein (1986). 


\section{Table 3}

\section{Growth of GNP and Debt}

\begin{tabular}{|c|c|c|c|}
\hline & 1060.69 & 1970.79 & 1980.86 \\
\hline 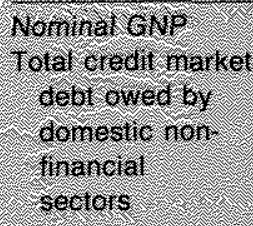 & $6890 \%$ & 1020 & 1065 \\
\hline v. S. goveriment & 1.95 & 67 & 10.76 \\
\hline 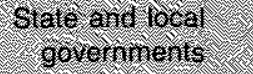 & 7.6 & 7.27 & 869 \\
\hline Tourehous & 864 & 1) & 9.96 \\
\hline Sevrorate & 8. 4.7 & 909 & 10.41 \\
\hline Tam copporate & 605 & 12.56 & -0.31 \\
\hline 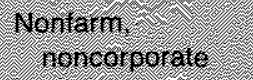 & 18,51 & 1607 & 18.18 \\
\hline
\end{tabular}

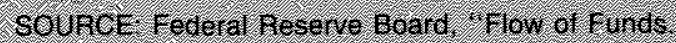
NOTE nil dathar annubl berentage changes.

net effect on social wealth is negative. But, for example, even if LBOs had no effect on the firm's performance, the net effect of LBO activity on tax revenues is unlikely to be negative. While the tax liability of the target firm falls with increased leveraging, that of the shareholders realizing capital gains and new bondholders increases. Moreover, the evidence that the tax benefits do not fully explain the observed gains to shareholders suggests that the gains to shareholders do not simply come at the expense of taxpayers. ${ }^{31}$ Thus, the argument that the gains to shareholders are offset by losses to taxpayers ignores the future increased tax base resulting from the LBO's predicted effect on the firm's productivity. If LBOs enhance the firm's performance, then income subject to taxation would increase later; increased future tax revenues would offset partially, if not fully, the loss in tax revenues now due to the use of debt finance in the LBO transaction.

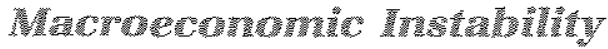

Some individuals have argued that the recent activity in the market for corporate control has contributed to an excessive growth of debt by nonfinancial borrowers in this decade. ${ }^{3 z}$ As table 3 shows, the growth of nominal GNP exceeded that of total debt of nonfinancial borrowers slightly during the 1960 s and was marginally smaller in the $1970 \mathrm{~s}$. In the $1980 \mathrm{~s}$, however, the growth of total outstanding debt for nonfinancial borrowers exceeded that of nominal GNP by more than 3 percentage points. Table 3 indicates that all borrowers contributed to this recent trend except for the farm, and nonfarm, noncorporate sectors. But the primary contributors appear to be the U.S. government and the corporate sector. ${ }^{33}$

Some observers have suggested that the growth rates of corporate and public debt, which appear high relative to GNP growth in the 1980s, especially by post-World War Il standards, reflect a greater instability in financial markets and, hence, the economy. According to this view, for any given slowdown in economic activity, the higher degree of leveraging by firms implies a greater likelihood that these firms will be forced to default on their debt obligations; if the affected creditors who suffer from deficient cash flows, in turn, are unable to service their own debt, then the severity of a slowdown in economic activity will be aggravated as the incidence of default is transmitted throughout the financial system. ${ }^{34}$

Despite the fact that the recent growth in corporate debt and LBO activity appear to be striking, whether or not these new trends indicate a threat to the stability of the financial system or

\footnotetext{
${ }^{31}$ See evidence cited in footnote 23.

32See Friedman (1989) and Kaufman (1989), for example. Gilbert and Ot (1985) found that the increase in corporate merger activity financed with debt (including $L B O S$ ) accounted for a substantial amount of the unusually large growth of business loans in the first half of 1984 .

33During the 1980s, corporate debt growth has exceeded nominal GNP growth in all but two years and by as much as 9.96 percentage points. See also Bernanke and Campbell (1988), who provide a detailed analysis of the recent trends in corporate debt. They look at disaggregated data in an attempt to determine the financial stability or solven-
}

cy of those firms most 非ely to default on their debt obligations.

${ }^{34}$ See, for example, "Taking the Strain of America's Leverage" (1988) and Ferguson (1989), Kautman (1986, 1989). Friedman $(1986,1989)$ and Greenspan (1989, especially p. 269). Friedman (1989) also argues that 'because of the increased likelinood of debtors' distress in the event of an economic downturn, the Federal Reserve system is likely to be less willing either to seek or to permit a business recession in the United States." According to Friedman, a consequence of the higher degree of leveraging is the prospect for greater inflation. 
the economy is not obvious. If LBOs or, more generally, merger and acquisition activity had no other benefit than providing a channel through which tax advantages of debt finance could be realized, then the growth of debt that only recently has significantly exceeded the growth of nominal output might seem alarming.

The existing empirical evidence briefly discussed above, however, suggests that LBOs provide anticipated gains over and above the tax gains to the target firm. Since these anticipated benefits include enhancing the earnings potential of the firm, simply comparing debt growth with nominal GNP growth does not provide a complete picture from which to identify the effects of debt growth on the stability of financial markets. Specifically, the increased debt as a fraction of nominal output could reflect an increase in expected future cash flows relative to the prior post-World War II trends. In this case, the increased debt would be associated with a rise in the market value of firms' assets. Indeed, aggregate debt-to-asset ratios, which more accurately indicate financial stability, hardly changed on net from 1969 to 1986. For example, one measure of this ratio using "flow of funds" data, rose from 34 percent in 1969 to 42 percent in 1986, peaking in 1974 at 51 percent. ${ }^{35}$

Aggregate debt-to-asset ratios, however, can be misleading, because they mask the financial condition of those firms with especially high debt-to-asset ratios. In fact, such firms have exhibited only a slightly higher increase in debt-toasset ratios than would be suggested by the aggregate data. Specifically, a recent study found that while, for a full sample of firms, the debtto-asset ratio fell from 31 percent in 1969 to 27 percent in 1986, for those firms in the 99th per. centile that is, having a higher debt-to-asset ratio than 99 percent of the sample), debt-toasset ratios rose from about 74 percent to 82 percent. $^{36}$

\section{SOMP UNANSWERED QURSTONS AND POUCY IMPLICATIONS}

The existing evidence cannot rule out the validity of all critical concerns about LBOs. In particular, most research on LBOS has examined the impact of the transaction on pre-buyout stockholders and bondholders of the firm. As such, these studies provide evidence on financial market participants' expectations about the impact of LBOs on the target firms perfor. mance. Although these stucies generally indicate that these transactions on average are expected to generate gains beyond tax liability reductions, we will have to wait to see if these gains are actually realized. Several recent studies on postbuyout performance of LBO firms provide evidence suggesting that those transactions, on average, have actually improved the firm's performance; however, evidence is preliminary and particularly subject to many methodological problems due to data limitations. ${ }^{37}$ Nevertheless, without evidence that LBOs are harmful or are likely to be harmful to the economy, policy actions to restrict $L B O$ activity seem to be premature; indeed, such restrictions could themselves be harmful, especially if LBO activity actually enhances the productiveness of the target firms.

\footnotetext{
${ }^{35}$ Bernanke and Campbell (1988), table 3, p. 98.

3olbid., lable 5, p. 104. As predicted by the "free cash flow" theory, the study found a dramatic increase in real and nominal interest expenses as a percentage of cash flows over this same period (see tables 6 and 7, pp. 106-07). Because expectations about increased future cash flows (as reflected in the increased market value of the firms' outstanding assets that has left debt-to-asset ratios virtually unchanged on net from 1969 to 1986) might not be fulfilled, however, concerns about recent trends in debt growth are not entirely unwarranted. Another recent study found that the default rate on junk bonds, commonly used to finance transactions in the market for corporate control, could be as high as 34 percent, much thigher than the average 2.5 percent reported by an earlier study. See Laderman (1989b) for a briei discussion of these two studies and Mitcheli (1989) and Fidler and Cohen (1989) for discussions of a more recent study by Moody's Investors Services, Inc. Also see Passell (1989) who summarizes two other studies' indings that the greater risk of default has been compensated by higher realized returns on average.
}

37For example, see Deveny (1989), who discusses a recent study indicating that companies involved in the matket for corporate control have not, on average, exhibited a decrease in expenditures on research and development, as predicted by some critics. Also, see Yago (1989), who reports one study's finding that target firms of management buyouts are less likely to close plants than are other firms. Francis (1989) discusses evidence from another study indicating that, upon a change in ownership of a firm, the ratio of the administrative employees to plant employees fell 11 percent on average. Indeed, one study found that for LBO firms between 1984 and 1986, average annual growth of the firm's productivity (measured by sales per employee) increased from an average of 3.6 per cent before the transaction to 17.4 percent after the transaction. See Yago (1989). Also, Palmeri (1989) recentiy found that the stocks of $70 \mathrm{LBO}$ target firms that subsequently went public performed significantly better than the market since going public. But see Long and Ravenscraft (1989) for a brief summary of a few other existing studies providing mixed evidence on post-LBO performance and a critical assessment of the validity of these studies. 
Although the recent behavior of various debtto-asset ratios does not indicate a drastic deterioration of corporate solvency, the higher debt-toincome ratios do suggest some increased risk of financial stress. That is, the recent behavior of these latter ratios indicate a higher degree of pressure on cash flows exerted by interest expenses (a reduction in liquidity), which could exacerbate the severity of any given slowdown in economic activity. To the extent the tax advantages of debt finance are not necessary to realize the gains from LBO activity, as well as from other highly leveraged transactions in the market for corporate control, a change in public policy might be warranted.

A widely discussed policy recommendation intended to slow the growth of all corporate debt involves eliminating the tax advantages of debt finance, in particular, by eliminating the tax deductibility of interest payments on debt. ${ }^{38}$ Another policy recommendation would involve removing the double-taxation of dividends by relieving the tax burden on dividends at the corporate level or stockholder level. Whether the latter approach to curb debt growth is politically feasible, given the wide concern about the unprecedented growth in public debt along with explicit commitments made by the administration to reduce the budget deficit, remains unclear. In any case, if, as suggested by the empirical evidence, LBO activity has benefits in addition to the tax advantages, these tax reforms should be considered on their awn merits, not chiefly as a way to reduce LBO activity,

\section{PRFEPTCES}

"A Big Event for American Bonds," The Economist (October 29, 1988), p. 81

Bennett, Amanda. "A Great Leap Forward for Executive Pay," Wall Street Journal, April 24, 1989.

Bernanke, Ben S., and John Y. Campbell. "Is There a Cor" porate Debt Crisis?" Brookings Papers on Economic Activity (1:1988), pp. 83-125.

"Board Issues Guidelines for LBO, Other Highly Leveraged Loans ..." The Fed Letter, Federal Reserve Bank of Kansas City (April 1989), p. 1

"Corporate America Snuggles Up to the Buy-Out Wolves," The Economist (October 29, 1988), pp. 69-72.

DeAngelo, Harry, Linda DeAngelo, and Edward M. Rice. "Going Private: Minority Freezeouts and Stockholder Wealth," Journal of Law and Economics (October 1984), pp. $367-401$.

38For example, see "The Debt Deduction" (1988) and Friedman (1986, 1989) and Dowd (1989), Also see U.S. Conm
"The Debt Deduction," New York Journal of Commerce, November 29, 1988.

Deveny, Kathleen. "srogress Isn't Drowning in Debt-Yet," Business Week: Innovation in America (Special 1989 Bonus Issue), p. 110.

Dowd, Ann Reilly. "Washington's War Against LBO Debt," Fortune (February 13, 1989), pp. 91-92.

Ferguson, Douglas E. "Solving the Leverage Problem," New York Journal of Commerce, January 9, 1989.

Fidler, Stephen and Norma Cohen. "Widening the Junk Default Debate," Financial Times, July 20, 1989.

Fortier, Diana L. "Buyouts and Bondholders," Chicago Fed Letter (January 1989).

Francis, David R. "Takeovers Cut Central-Office Costs," The NBER Digest, June 1989.

Friedman, Benjamin M. "Increasing Indebtedness and Financial Stability in the United States" in Federal Reserve Bank of Kansas City, Debt, Financial Stability, and Public Policy (August 1986), pp. 27-53.

. "Tread Carefully on Takeovers," New York Journal of Commerce, April 27, 1989.

Gilbert, R. Alton, and Mack Ott. "Why the Big Aise in Business Loans at Banks Last Year?" this Review (March 1985), pp. 5-13

Greenspan, Alan. "Statement Before the Committee on Ways and Means, United States House of Representatives," Federal Resenve Bulletin (April 1989), pp. 267-72.

Jarrell, Gregg A., James A. Brickley, and Jeffry M. Netter. "The Market for Corporate Control: The Empirical Evidence Since 1980," Joumal of Economic Perspectives Winter 1988), pp. $49-68$.

Jensen, Michael C. "Takeovers: Their Causes and Consequences," Journal of Economic Perspectives (Winter 1988), pp. 21-48.

"Agency Costs of Free Cash Flow, Corporate Finance, and Takeovers," American Economic Review (May 1986), pp. 323-29.

Jensen, Michael C., and William $H$. Meckling. "Theory of the Firm: Managerial Behavior, Agency Costs and Ownership Structure," Journal of Financial Economics (October 1976), pp. $305-60$.

Jensen, Michael C, and Richard S. Ruback. "The Market for Corporate Control: The Scientific Evidence," Journal of Financial Economics (April 1983), pp. 5-50.

Kaufman, Henry. "Halting the Leverage Binge," Institutional Investor (April 1989), p. 23.

"Debt: The Threat to Economic and Financial Stability," in Federal Reserve Bank of Kansas City, Debt, Financial Stability, and Public Policy (August 1986), pp. $15-26$.

Laderman, Jeffrey M. "Earnings, Schmernings-Look at the Cash," Business Week (July 24, 1989a) pp. 56-57. ."Does Junk Have Lasting Value? Probably," Business Week (May 1, 1989b), pp. 118-19.

Lehn, Kenneth, and Annette Poulsen. "Free Cash Flow and Stockholder Gains in Going Private Transactions," Journal of Finance (July 1989), pp. 771-87.

gress, Joint Committee on Taxation (1989) for a more detailed and exhaustive list of policy proposals. 
"Leveraged Buyouts: Wealth Created or Wealth Redistributed?" in Murray L. Weidenbaum and Kenneth W. Chilton, eds., Public Policy Toward Corporate Takeovers (Transaction Inc, 1988), pp. 46-62.

Long, Willam $F_{2}$, and David J. Ravenscraft. "The Record of LBO Performance," mimeo (May 17, 1989).

Lowenstein, Louis. "No More Cozy Management Buyouts," Harvard Business Review (January/February 1986), pp. 147.56 .

"Management Brief: The Way the Money Goes," The Economist (Uuly 15, 1989), pp. 70-71.

Manne, Henry G. "Mergers and the Market for Corporate Control," Journal of Political Economy (April 1965), pp. $110-20$.

Marals, Laurentius, Katherine Schipper and Abbie Smith. "Wealth Effects of Going Private For Senior Securities;" Joumal of Financial Economics (June 1989), pp. 155-91,

Merrill Lynch Business Brokerage and Valuation, Inc., Mergerstat Review (1988).

Mitchell, Constance. "Junk'lssuer Rate of Default is Put at Average 3.3\%," Wall Street Journal, July 20, 1989.

Mitchell, Mark L., and Kenneth Lehn. "Do Bad Bidders Become Good Targets?" mimeo (August 1988).
Ott, Mack, and G.J. Santoni. "Mergers and Takeovers-The Value of Predators" Information," this Review (December 1985), pp. 16-28.

Palmeri, Christopher. "Born-Again Stocks," Forbes (March 20, 1989), pp. 210-11.

Passell, Peter. "Economic Scene: The $\$ 12$ Billion Misunderstanding:" New York Times, July 17, 1989.

Stancill, James McNeill. "LBOs for Smaller Companies," Harvard Business Review (January/February 1988), pp. 18-26.

"Taking the Strain of America's Leverage:" The Economist (November 5, 1988), pp. 87 88.

Thomson, James B. "Bank Lending to LBOs: Aisks and Supervisory Response," Economic Commentary, Federal Reserve Bank of Cleveland (February 15,1989 ).

Torabzadeh, Khall M., and Wiliam J. Bertin. "Leveraged Buyouts and Shareholder Returns," Journal of Financial Fesearch (Winter 1987), pp. 313-19.

U.S. Congress. Joint Committee on Taxation. Federal income Tax Aspects of Corporate Financial Structures, (GPO, 1989).

"When industry Borrows Itself," The Economist (October 29, 1988), pp. 17-18.

Yago, Glenn. "LBOs, UFOs and Corporate Perestroika," Wall Street Journal (July 19, 1989). 